DE DE GRUYTER OPEN

Balwant Samra

Coventry University

Anna Wos*

Coventry University
Journal of Intercultural Management

Vol. 6, No. 4, December 2014, pp. 263-288

DOI 10.2478/joim-2014-0050

\title{
Consumer in Sports: Fan typology analysis
}

\begin{abstract}
Sport fan loyalty is important to attain within a culturally rich and global audience as loyal sport fans are unique consumers. The ability to adequately understand what motivates the sports consumer is an important requirement for sport managers. This paper proposes that a greater understanding of fandom will contribute to a better understanding of the concept of loyalty. Although there is research regarding typology of fans and loyalty, but even within sport advocates group there may be sub-categories that can explain loyalty behaviour further. This research analyses types of sport fans in different disciplines in the UK, as an example of diverse society to explore factors determining category of fans.
\end{abstract}

Key words: consumer, sport, fan typology

\section{Introduction}

Sports consumers display a bewildering array of values, attitudes, and behaviours (Mir 2000; Shank 2002; Westerbeek and Smith 2003). Not all sports consumers are equally passionate and fanatical nor use their team to confirm their personal identity (Redden and Steiner 2000). Neither are they totally loyal, engrossed in club history, or resistant to change that threaten team values and practices. Some attend games on a regular basis, while others attend only on special occasions. Some consumers spend most of their time engaging in sport chatter trawling the internet, while others display their fandom by watching pay television sport channels. They experience sport in different ways, and use the team affiliation to meet a diverse range of needs (Wann, Melnick, Russell and Pease 2001).

\footnotetext{
* anna.wos.84@gmail.com
} 
The ability to adequately understand what motivates the sports consumer is an important requirement for sport managers (Brooks 1994). Understanding different spectator motivations can be of significant benefit to the sport marketer looking to boost team revenues and gate receipts. Of particular interest are both the marketing manager understanding the specific motivations that drive a spectator or fan to consume sport (Bernthal and Graham 2003) and the subsequent development of marketing communications based on these motivations (McDonald et al 2002). These effective marketing communication plans can often help build groups of "fanatical fans", thus expanding the customer base for a team (Pease and Zhang 2001). What motivates consumers to become emotionally committed to a brand is particularly important to marketers. In a sporting context where fans demonstrate extreme forms of emotional commitment an ultimate version of brand commitment can be demonstrated. Understanding different forms of fanship may provide insight generically to consumer loyalty patterns and specifically provide insight into sporting behaviour for the marketer.

Sport fan loyalty is important to attain within a culturally rich and global audience as loyal sport fans are unique consumers: their commitment to a sport team is "arguably unparalleled in other business or leisure sector" (Tapp and Clowes 2002:126). While many industries face the problem of declining brand loyalty amongst their customers (Lipke 2001), the sporting industry has lifelong fans that demonstrate tremendous loyalty and devotion, even to teams with a long history of poor performance (Bristow and Sebastion 2001).

This paper proposes that a greater understanding of fandom will contribute to a better understanding of the concept of loyalty. Although there is research regarding typology of fans and loyalty, but even within sport advocates group there may be sub-categories that can explain loyalty behaviour further.

\section{Conceptual Framework}

The word 'fan' has been used in various disciplines from sociology to marketing in management. It is an abbreviation from fanatic. Fanatic derives from the Latin "fanaticus" which literally means "a temple servant, a devotee". It also refers to people "inspired by orgiastic rites and enthusiastic frenzy" (Jenkins 1992). It has also been described as sacred or beneficial (Rudin 1969: 12). In the course of time, the word has been used in a reference to any excessive enthusiasm which is considered with religious zealotry, false beliefs, orgiastic excess, possession and madness.

\section{Unique features of Fans as consumers}

On the basis of the sociological and managerial description about fans outlined above, three unique features of the fans as consumers can be identified as follows: 
Fans possess a strong and intense emotional attachment with the consumption objects. Emotional affiliation has been used to distinguish the fan from general consumers. Jenkins (1992) identifies the differences between watching a TV drama series and becoming a fan of the drama as lying in the intensity of the fan's emotional or intellectual involvement. Grossberg (1995) observed that a fan is more closely associated with a particular form of intensity or affect compared to general customers. Following Oliver's $(1980,1991,1999)$ classification of stages of loyalty, fandom cannot be reached unless the object is part and bundle of the consumer's self identity and his or social identity. Abercombie and Longhurst (1998) place the position of fan on a continuum of audience experience and identities which range from the consumer at one end, to the producer on the other end of the scale, taking in the fan, the enthusiast and the cultist along the way. Sports consumers form psychological connections to specific teams that are persistent and resistant to change (Kolbe and James 2000; Trail and James 2001). Kolbe and James found consumers themselves as part of the team, demonstrating a strong psychological commitment.

Fans behave as loyal consumers who exhibit several loyalty behaviours, such as repeating their purchase or patronage, or insisting on staying in the relationship between brands or products. Regular and repeated consumption is the clearest indicator of a particular emotional investment of the fan in the literature. Brooker and Jermyn (2002) and Harrington and Bielby (1995) identify the relationship between repeated consumption and the emotional commitment of these fans. Sandvoss (2005) observes that most of those who labelled themselves as fans, pointed to their repeated consumption patterns. He defines fandom on the basis of repeated consumption and emotional bond with the fanatic objects and his description of the fan equates with consumer loyalty behaviour. Such loyal behaviour is a composite blend of brand, an attitude and behaviour with indexes that measure the degree to which the consumer favours and purchases a brand repeatedly (Day 1969, Pritchard and Howard 1997).

Fans present informal membership behaviours, such as co-production and investment. The relationship between fans and the object tends to always be active and proactive. Active participation on production processes distinct fans from general consumers. Among television fans, (Jenkins 1992) found some media fans as consumers who also produced, such as readers who also wrote, and spectators who also participated. In a similar vein, Grossberg (1995) addresses that fandom creates something more than consumption of cultural objects and actively produces views on the objects. Cavicchi (1998) notes, that fans are specialist consumers, in one sense, they are consumers whose consumption habits are highly predictable and are likely to remain stable. Fans want to get involved with production of the object rather than simply repurchasing or possessing it. Consequently, the fan's intense consumption is valued by uniting consumption with the cultural values of production. 
In the marketing context, Bhattacharya (1998) characterises the consumer who has greater affiliation with the organisation as informal membership, which implies that highly loyal consumers are more actively involved in the organisation's activities as a co-producer. Unlike the traditional view on the consumer loyalty which focuses on consumers repurchase or repatronage, membership motivates the consumer to help the organisation by volunteering time and gifting money to support the mission of the organisation.

In sociology studies, fandom is used to portray the interaction between audience and popular media within culture studies (Horton and Wohl 1956; Schikel 1986). From the late 1980's Fiske (1989) and Jenkins $(1991,1992)$ were the first to put emphasis on fans and fandom in media and cultural studies. Fiske (1989) and Jenkins (1992) introduce the concept of motivation and the interaction between fans and the objects of their fanaticism. A fan is generally viewed as an obsessed individual someone who has an interest in a certain team, celebrity, show, brand and the like (Hills 2002). Fiske (1992) has defined fandom as a consequence of specific social and cultural interactions, institutions and communities, formed through the close interaction of committed groups of fans in a sub-cultural context. Sport fandom can enhance psychological well-being and the quality of life (Curtis et al 1986; Giamatti 1989; Grove et al 1982; Smith 1989, 1981). It has been argued that identification with sport teams may serve to replace traditional but declining social ties such as religion and the family (Branscombe and Wann 1991; Melnick 1993; Putnam 1995, Melnick and Wann 2011). Social connections resulting from sport identification may prove beneficial to ones psychological health by serving as a buffer against depression and alienation while increasing self-esteem (Pan et al 1997; Smith 1988, 1989; Zillman et al 1989; Keaton and Gearhart 2014).

Sport fandom is a subject of research in many dimensions such as sport fandom and affective expression (Ferguson 1981, Coakley 1994), sport fandom as performance entertainment (Lancaster 1997, Wann et al 1997), sport fandom and communication (Hardaway 1976; Seagrave 1994), sport fandom and religion (McGee 1975, Novak 1976), sport fandom and national identity (Goodger and Goodger 1989), sport fandom and integration (Lever 1983, Wilkerson and Dodder 1987; Melnick 1993) or fans in management (Hill 2001; Kozinets 2002; Sandvoss 2005). This rich research around sport fandom indicates importance of it for marketers and academics.

\section{Fans in Sport}

Sport fans are typically thought to have a stronger emotional commitment and response than non-fans when viewing sport (Gantz and Wenner 1995). Hunt, Bristol and Bashaw (1999: 440) formally define a sport fan as 'an enthusiastic devotee of some particular sports consumptive object' The notion of being a fan in popular culture has in some cases been seen as a negative (Jenkins 1992; Jenson 1992), but 
others authors see it in a much more positive light and that being a fan can be therapeutic act (Fisk 1992; Wenner 1990). Pooley (1978: 14) suggests that casual sport spectators are simple observers and soon forget about a sporting event at its conclusion, whilst more committed fan is said to "continue his interest until the intensity of feeling toward the team becomes so great that parts of every day are devoted to either his team or in some instances, to be broad realm of sports in general". The distinction is best made by Guttmann (1986) where the term fan refers to the emotionally committed consumer of sports events. The terms overlap but are obviously not identical. In practice most fans are spectators and most spectators are fans, but it is logically possible to be one and not the other.

Spectators are a key constituent of a sport organisation's success - greater fan numbers attract sponsors. A form of double jeopardy exists - sports that attract small crowds are unlikely to attract large sponsorship deals or negotiate lucrative television rights, further reinforcing the sport's low profile and its unattractiveness for sponsors. Fans are the demand nodes; differences in demand according to spectator characteristics are recognised. A number of sport fan studies, reviewed by Quick (2000), have suggested that not all fans are motivated by the same factors. Various typologies of fan attendance abound in the sport fan academic literature with many relying on product usage rates (levels of spectatorship) for their classifications. The terms "theatre- goers", "fair-weather fans" and "hardcore fans" connote attendance status as well as commitment to the sport/team. Typically, "theatre-goers" and "fair-weather fans" display temporal and situational involvement with their team/sport whereas "hardcore fans" display enduring involvement (Madrigal 1995). Implicit in most sport marketing activity is the desire to move spectators up the attendance/participation escalator (akin to Christopher, Payne and Ballantyne's 1991 "ladder of loyalty") thereby turning light users ("theatre- goers" and "fair-weather fans") into heavier users.

Quick (2000) summarises the heterogeneity of sport fan spectatorship. "The tribal, hard-core fan is but a minor figure in the professional sportscape. In recent decades a number of other fan segments have been identified, each having a different expectation of the sport experience. Moreover, each group, whether consuming the sport product at the event, on the street, or over the Internet, has unique value to the sport organisation; because of this, if possible, the needs and experiences of each group must be accommodated" (Quick 2000: 150). From previous research undertaken three types of fans have identified (refer to Table 1). 
Fan types

Table 1: Fan types

\begin{tabular}{|c|c|c|c|}
\hline $\begin{array}{l}\text { Fan Cat- } \\
\text { egory }\end{array}$ & Literature & Motivation & Classification \\
\hline $\begin{array}{l}\text { Temporary } \\
\text { Fan }\end{array}$ & $\begin{array}{l}\text { Champ follower } \\
\text { (Stewart/ Smith1997) } \\
\text { Theatregoer (Stewart/ } \\
\text { Smith 1997) } \\
\text { Carefree/Casual (Tapp/ } \\
\text { Clowes 2000) } \\
\text { Aficionados (Stewart/ } \\
\text { Smith1997) Corporate fan } \\
\text { (Nash 2000), } \\
\text { Modern/Fan (Boyle/ } \\
\text { Haynes 2000) } \\
\text { Social/fan (Sutton et al } \\
\text { 1997) } \\
\text { Less Loyal (Bristow/Se- } \\
\text { bastian 2001) }\end{array}$ & $\begin{array}{l}\text { Emotional Stimulation } \\
\text { (M) } \\
\text { Group Affiliation (L) } \\
\text { Group Disassociation } \\
\text { (L) } \\
\text { Economic }(\mathrm{H}) \\
\text { Self Identity }(\mathrm{L}) \\
\text { Information } \\
\text { acquisition }(\mathrm{M})\end{array}$ & $\begin{array}{l}\text { Brand Commitment (L) } \\
\text { Personal Commitment (M) } \\
\text { Enduring involvement (L) } \\
\text { Situational/involvement (H) } \\
\text { (Hirt et al 1992) } \\
\text { Advocacy (L) (Oliver 1999, } \\
\text { Tapp 2004) } \\
\text { Usage (L) (DeSchriver/Jensen } \\
\text { 2002, Funk et al 2002,Hansen/ } \\
\text { Gauthier 1989) }\end{array}$ \\
\hline $\begin{array}{l}\text { Devoted } \\
\text { Fan }\end{array}$ & $\begin{array}{l}\text { Committed casual (Hunt } \\
\text { et al 1999) } \\
\text { Focused Fan } \\
\text { (Sutton et al 1997) } \\
\text { Passionate Fan } \\
\text { (Stewart/Smith 1997) } \\
\text { Traditional Fan } \\
\text { (Boyles/Haynes 2000) }\end{array}$ & $\begin{array}{l}\text { Emotional Stimulation } \\
(\mathrm{M}) \\
\text { Group Affiliation }(\mathrm{H}) \\
\text { Group Disassociation } \\
(\mathrm{M}) \\
\text { Economic }(\mathrm{H}) \\
\text { Self Identity }(\mathrm{M}) \\
\text { Information } \\
\text { acquisition }(\mathrm{M})\end{array}$ & $\begin{array}{l}\text { Brand Commitment }(M) \\
\text { Personal Commitment }(M) \\
\text { Enduring involvement }(M) \\
\text { Situational/involvement }(\mathrm{H}) \\
\text { Advocacy }(\mathrm{M}) \\
\text { Usage }(\mathrm{M})\end{array}$ \\
\hline $\begin{array}{l}\text { Fanatical } \\
\text { Fan }\end{array}$ & $\begin{array}{l}\text { Die Hard } \\
\text { (Sebastion 2001) } \\
\text { Fanatical Fan } \\
\text { (Hunt et al 1999) } \\
\text { Vested Fan } \\
\text { (Sutton et al 1997) } \\
\text { Passionate Fan } \\
\text { (Stewart/Smith 1997) } \\
\text { Traditional Fan } \\
\text { (Boyles/Haynes 2000) }\end{array}$ & $\begin{array}{l}\text { Emotional Stimulation } \\
(\mathrm{H}) \\
\text { Group Affiliation }(\mathrm{H}) \\
\text { Group Disassociation } \\
(\mathrm{H}) \\
\text { Economic }(\mathrm{L}) \\
\text { Self Identity }(\mathrm{H}) \\
\text { Information } \\
\text { acquisition }(\mathrm{M})\end{array}$ & $\begin{array}{l}\text { Brand Commitment }(\mathrm{H}) \\
\text { (Doss1999,Muniz/ } \\
\text { O’Guinn2001, } \\
\text { Personal Commitment (H) } \\
\text { (Funk1998,Muniz/O'Guinn } \\
\text { 2001) } \\
\text { Enduring involvement (H) } \\
\text { (Redden/ } \\
\text { Steiener2000,McAlexander et } \\
\text { al 2002) } \\
\text { Situational/involvement (H) } \\
\text { Advocacy (H) (Hugenberg } \\
\text { 2002) } \\
\text { Usage (H) (Hoffman2000) }\end{array}$ \\
\hline
\end{tabular}




\section{Types of fans}

\section{Temporary Fan}

The stronger an individual identifies himself or herself as a "fan" the more the individual uses this specific identification with regard to external others and internally, to discern himself or herself. However, being a fan is not used by the temporary fan for self identification (i.e. being a fan is not central to the temporary fan's self concept). The temporary fan's interest in the phenomenon is time constrained. After the phenomenon of interest is over, the fan is no longer motivated to exhibit behaviour related to the sports object, but rather return to normal behaviour.

This time boundary is the primary factor that differentiates the temporary fan from other sports fans. What might explain a temporary fan's motives and behaviour? Cialdini et al (1976) suggested basking in reflected glory theory (BIRG) as a way to understand fans. It involves the tendency for an individual to attempt to internalize the success of others.

Devoted fan

The devoted fan remains loyal to their team or player even if either the specific, short -term event that captivated their temporary attention has ended or if they are removed from the context of the original geographical location. According to Ball and Tasaki (1992), a person is attached to a particular object to the degree that the object is used to maintain his or herself concept. The more an object constitutes part of a consumer identity, the more the consumer exhibits protective behaviour toward the object, the greater the effort the consumer spends on maintaining the object, the greater the consumer's emotional difficulty in accepting deterioration or loss of the object. Thus, neither BIRG nor cuttings of reflected failure (CORFing) explain the motives and behaviours of devoted fan. The devoted fan possesses an attitude of my "team right or wrong". The devoted fan uses being a fan as an important part of self-identification, yet not the most critical or central self-definition in one's life.

\section{Fanatical Fan}

Early explorations of social psychology theories currently adopted in sport sociology research of fan loyalty provide preliminary insights that help develop our understanding of the development of fanaticism and this unique form of intense loyalty. For example, the concept of socialisation provided explanations that can explain the process by which individuals are introduced to the brand that later becomes the object of fanaticism, e.g. socialising agents such as family, peers, school and community attract or draw individuals to learn to accept the values, goals, 
beliefs, attitudes, and norms of the fan culture (James 1997; Huffman et al 2000; Wann et al 2001). Social identity and self-esteem maintenance theories help explain how an individual may develop an attraction to an object, and, attachment theories for insights into how a person may become fanatical via the process of attachment. Consumer fanaticism is a unique form of loyalty characterised by strong and intense levels of commitment, allegiance, devotion, passion, emotional attachment, enthusiasm and involvement (Bristow and Sebastion 2001; Cova and Cova 2002; Funk and James 2001 Muniz and O'Guinn 2001; Oliver 1999; Redden and Steiener 2000; McAlexander et al 2002). Fans are unique consumers because their interest in a brand is self-sustaining (Pimental and Reyonlds 2004). They voluntarily engage in behaviours beneficial protecting the brand, and ensuring the brand's continued existence and legacy (Doss 1999, Fournier 1998, Fournier and Yao 1997; Pimental and Reynolds 2004; Rozananski et al 1999). Fanatical consumers exhibit a deep love for the brand and remain loyal despite poor brand performances (Hugenberg 2002; Hunt, Bristol and Bashaw 1999; Rifkin 1999; Whang et al 2004). They display a true admiration for the brand, and their devotion, passion, and enthusiasm are often considered infectious in attracting new customers and fellow followers (Belk 2004; Pimental and Reyonalds 2004; Rifkin 1999).

Fanatics are valuable customers of a brand and attractive to marketers due to a variety of reasons. For example, some fanatics have extreme consumption drives, which imply heavy usage and purchase patterns (Huffman 2000). They act as opinion leaders to bring others' attention to the brand and attract new customers on behalf of the company (Rifkin 1999). Fanatics venture to great personal and financial lengths to support the brand, such as by joining and actively participating in brand communities (Funk 1998; Muniz and O'Guinn 2001). Their support is consistent, persistent and resistant to any attempts at reducing this attachment, which includes the active disregard of marketing messages from competitor brands (James 1997) Hugenberg (2002: 178) explains that organisations become wealthy as a result of fan loyalty.

The fanatical fan is similar to the devoted fan in that the fanatical fan is not bounded by time or distance and defines self through attachment with the sports consumptive object. The fanatical fan uses being a fan as a very important part of self identification. The fanatical fan engages in behaviour that is beyond the normal devoted fan, greater level of knowledge, greater level of anxiety and arousal watching their team compete (Branscombe and Wann 1992; Wann et al 1998) yet the behaviour is accepted by significant others (family, friends, other fans) because it considered supportive of the team, player or sport. Devoted fan may go to games. Fanatical fan may go to the game and paint their body with colours of the team, or go in costume, or in some way exhibit behaviour that is different from the devoted fan. Interaction with the club is highly valued. Supporters engage in web site discus- 
sions and email commentaries, are keen in joining supporter groups, and actively seek out and subscribe to newsletters and fanzines.

\section{Involvement}

Involvement has been defined as a state of motivation, arousal, or interest toward a recreational activity or associated product (Rothschild 1984). Involvement represents an internal state variable that reflects the amount of arousal, interest, or drive evoked by a particular stimuli or situation that mediates consumer behaviour (Mitchell 1979). Involvement research delineates situational involvement from enduring involvement (Houston and Rothschild 1978; Richins and Bloch1986; Richins et al 1999).Enduring involvement is conceptualized as the ongoing baseline level of concern with an activity or product, i.e. individuals ongoing concern with the team. Situational involvement is a passing increase in concern for the activity or product due to temporary circumstances (Richin and Bloch 1991). For example, a fan that is preparing to attend may have high situational involvement on that evening. Thus, enduring involvement represents an individual's ongoing level of interest in an activity or product class (Houston and Rothschild 1978). Enduring involvement is independent of situations. High levels of enduring involvement are likely to occur when the individuals perceive an activity or product offers hedonic benefits or is closely linked with the self (Laurent and Kapferer 1985).

Loyalty

The concept of loyalty has earned considerable attention in the broad area of consumer behaviour, and the importance of studying loyalty has been recognised more than ever (Oliver 1999). The construct of loyalty has evolved within a framework of behavioural, attitudinal and composite concepts. First loyalty was defined as an overt behaviour or consequence of behaviour (Cunningham 1956). Therefore, it centred on repeat purchase patterns of the same brand over time. Later, attitudinal component of loyalty earned attention as a better way of understanding the underlying psychological phenomenon behind the behaviour. Thus, the attitudinal definition of loyalty focused on the position of the object along a continuum of customer preference (Day 1969). Then, the composite conceptualization of loyalty emerged. In this notion, loyalty is viewed as a two dimensional phenomenon that is a function of favourable attitudes and behavioural repetition over some period (Jacoby and Kyner 1973). This concept allows researchers to categorise the extent of loyalty as high, spurious, latent and non-existent (Backman and Cromton 1991a; Dick and Basu 1994).

In the sports literature, fan loyalty and identification with the team are seen as the main determinants of fan behaviour. The popularity of fan loyalty is probably due to the fact that loyalty of sports fans is in some ways dysfunctional. Sometimes, 
loyalty is increasing the worse the team is performing (Bristow and Sebastion 2001). Hence, in contrast to the assumptions in sport economic literature, satisfaction with the outcome of the game appears to have little link to loyalty at least for some of the sports fans.

Attitudinal dimension of fan loyalty is represented by the psychological commitment of a fan to the team. Commitment is typically defined as the emotional or psychological attachment to brand (Beatty and Kahle 1988). Previous measures of fan's psychological commitment have included three components of commitment: inner attachment, persistence and resistance (Gladden and Funk 2001; Mahony et al 2000; Pritchard et al 1999). Fans therefore show a high level of psychological commitment if they feel a deep inner attachment to their favourite team and if their commitment is persistence overtime and resistant to criticism. In the organizational behaviour literature commitment has been examined extensively (Meyer and Allen 1984), suggests that measure of commitment should also include indicators regarding the degree to which individuals care about the long term success of the organization (O'Reilly and Chatman 1986), in this case favourite football club or team. Wakefield and Sloan (1995: 159) define team loyalty as an "allegiance or devotion to a particular team that is based on the spectator's interest in the team that has developed overtime".

Behavioural loyalty represents past behaviour as well as behavioural intentions (Homburg and Giering 1999). Past behaviour comprises past purchasing behaviour and past positive word of mouth. By transferring the loyalty concept to fan behaviour, the following activities constitute past loyal behaviour in the team sport context: attending the favourite club's games live in the stadium, watching the favourite club's game on television, consuming other club-related media, purchasing club merchandise, wearing the colours or logo of their favourite club, and trying to convince others that the favourite club should be supported (Funk et al 2003; Funk and Pastore 2000; Gladden and Funk 2001; Mahony, Madrigal and Howard 2000; Shank and Beasley 1998).The intentional component represents the positive and persistent future behaviour of the fan. It embraces intended loyal behaviour and positive word of mouth, as well as cross buying intensions (Homburg and Giering 1999). Positive word of mouth is referred to as all informal communication between a consumer and others concerning evaluations of goods and services, including recommendation to others (Anderson 1998). Cross buying refers to a fan's practice of buying additional products and services from a favourite club brand in addition to the ones he or she currently owns (Ngobo 2004), particularly, relevant for sport marketers today because most professional clubs now have brand extension strategies whereby they are expanding the range of branded products and services beyond club merchandise (Apostolopoulou 2002; Chadwick and Clowes 1998).

In addition, loyalty of sports fans is fascinating because loyalty is important to 
them in a way that is not to consumers in most sectors (how many shoppers will sing 'loyal customers' as they make their weekly trip to Asda?) (Tapp 2004:204). Therefore, loyalty to a team is a highly meaningful concept for sports fans. While Parker and Stuart (1997) point out that exclusively loyalty to a team is the norm and that loyalty is not affected by team success at all, other author's state that loyalty of sports fans cannot be taken for granted. They emphasise that different types of sports fans show different type of loyalty and different behaviour depending on the team's success (Tapp 2004). Based on the work of Dick and Basu (1994) Tapp (2004) found a number of football supporter categories based on their attitudinal and behavioural loyalty to a team. On the one end of the spectrum is a fanatic and at the other end a supporter who attended only occasionally. Whereas fanatics will still be loyal to a team even when success is missing, casual supporters might cease to watch the games in such a situation. These different reactions are described by Cialdini et al (1976) as BIRGing (Basking in Reflected Glory) and CORFing (Cutting off Reflected Failure) behaviour. Several researchers have found that BIRGing and CORFing tendencies vary across different types of sports fans (Madgrial 1995, Sloan 1989). Wann and Branscombe (1990) found that individuals high in team identification were more likely to BIRG after a victory and less likely to CORF after defeat. Those fans are likely to support their team even when they drop down a league and satisfaction with the outcome of a game is not linked to their loyalty (Tapp 2004).

\section{Commitment}

Commitment, in marketing context, is used as the degree to which an individual views his/her relationship with consumption objects from a long-term perspective and is willing to stay with the relationship even when things are difficult. This concept of commitment has been used to measure marketing effectiveness. Day (1969) employed commitment to determine a more accurate description of loyalty. Jacoby and Kyner (1973) emphasise that the notion of commitment provide the essential basis for distinguishing between brand loyalty and other forms of repeat purchasing behaviour. Samuleson and Sandvick (1997) state that commitment describes a bond or attitude strength between a consumer and a particular brand, thus extending the meaning of loyalty and should go beyond simple repurchasing or repatronage. Amine (1998) addresses the feature of true brand loyalty, and regards it as effective buying.

\section{General sport consumer motivations}

Motivation has been defined as the driving force within individuals that impels them to actions McClelland (1951). He observed that a motive became a strong affective association, characterised by an anticipatory goal reaction and based on 
past association of certain cues with pleasure or pain. Murray (1964) extends the above description stating that, "a motive is an internal factor that arouses, directs, and integrates a person's behaviour... [a motive] is not observed directly but inferred from his behaviour or simply assumed to exist in order to explain his behaviour" (Murray 1964).

Hunt et al (1999) classification schema focuses on the source of motivation and on the behaviour exhibited by different types of fans. Similar to the concept of involvement, the linkage between motivation and actual behaviour can be temporary or enduring (Richins and Bloch 1986). For example if social pressures or temporary circumstances are the source of a consumer's motivation to engage in sports related behaviour, then such motivation is termed situational. Situational motivation is bound by time or space and thus is more temporary in nature. Conversely, if the source motivation is not context bound, then motivation is identified as enduring. Enduring motivation is likely, given that the fan perceives the sports object as important to his or herself-concept. Unlike situational motivation, enduring motivation has no such time or location constraints. The source of temporary and local fans motivation is situational, while the source of motivation for devoted, fanatical, and dysfunctional fans is enduring.

For those fans whose motivation with sports is more enduring, differences occur because of their level of attachment to the sports object (i.e. the degree of centrality of sport to self). Ball and Taski (1992) suggest that attachment is conceptually distinct because the object of attachment acquires meanings and significance beyond that of a simple involvement or importance. Fans reveal their level of attachment through their sports related behaviours. Devoted, fanatical fans differ in terms of their attachment to the sports consumptive objective, as exhibited by their behaviour towards that object.

\section{Group affiliation}

In most instances, sport spectating is a social activity (Danielson 1997). Whether it occurs at home, a restaurant, a bar, or the arena sport tends to be consumed in a group environment. For some individuals, it is precisely the social nature of sport spectating that attracts them to it. They are motivated by the group affiliation motive, that is, a desire to spend time with others (Gantz and Wenner 1995; Guttman 1986; Melnick 1993; Pan et al 1997; Sloan 1995; Smith et al 1981). Group affiliation is motivated by a desire for positive distinctiveness from other social groups (Madrigal 2002). Sport fandom and sport spectating can help to fulfil the human need for social interaction by providing a sense of belongingness. The fact that most spectators consume sport as a member of a social group suggests that fans do indeed use sport to satisfy social interaction needs (Mann 1969; Aveni 1977). For some fans, the opportunity to spend some time with friends is a driving mo- 
tivational force behind their decision to consume sport (Melnick 1993; Pan et al 1997, Melnick and Wann 2011). This motive is particularly common among sports fans that have children and or are married (Wann et al 1998). In affiliation, one important part of the identification process with the group is rituals like collecting, pilgrimages and viewing the club as a part of one's self identity. Consuming some brands becomes part of the integration.

\section{Self-identity}

Social identity theory, rooted in the symbolic interaction tradition, focuses on the connection between self, role and society (Stryker 1980). In this conceptualization, the self is composed of "multiple selves", some which are more important than others. This notion can be traced back to James (1890).This view of the self recognizes the social units that people live in are relatively small network of relationships that impact individuals identities. Kleine et al (1993) find that social identity perspective is useful way to study the many different types of consumption people routinely partake in. The role of identity theory is to understand how and why individuals select certain identity related activities, given all of the possible alternatives (Serp 1987). Shamir (1992) finds identity salience is related to commitment to participation in a leisure activity and to the time invested in the activity. Additional support, in the context of leisure is offered by Laverie (1998) who demonstrates that identity salience is an effective predictor of motivation for participation in a specific leisure activity. Social identity theory is applicable because fan behaviour is socially visible, involves relationships with others, can lead to the formation of a fan role and one can experience satisfaction associated with that role. Therefore, those with high level of identity salience for being a fan of a sporting team will attend more games than those low in identity salience.

\section{Economic}

For some individuals, it is the potential economic gain from sport gambling that attracts them to the role of a fan. These persons are driven by the economic motive (Chorbajian 1978; Eastman and Land 1997; Frey 1992; Gantz and Wenner1995; Guttmann 1986).

\section{Emotional Stimulation}

As is widely known, sport can provide fans with stress and stimulation. Fun and enjoyable stress often referred to as "eustress" is a major motivational factor for fan attraction (Madrigal 1995; Mahony and Moorman 1999). It involves a desire to gain excitement and stimulation through sport (Gantz 1981; Sloan 1986). Fans with high level of eustress (i.e. euphoric stress) motivation become involved with the pastime because they enjoy the excitement and arousal they experience watching 
sport, whether it's the drama of close game or escape from their everyday routines. Information acquisition

Many fans attend sports events to gain knowledge about the particular sport and improve on their physical fitness by watching these events (Ryckman and Hamel 1993; Elay and Page 1999; Koivulos 1999).

\section{Group disassociation}

Although many supporters of sport belong to a group, previous research (King 1997) has noted that that a minority support their teams in a solitary way.

Table 2: Motivation Table

\begin{tabular}{|c|c|c|c|}
\hline Motivation & Definition & Dimension & Authors \\
\hline $\begin{array}{l}\text { Group Affili- } \\
\text { ation }\end{array}$ & $\begin{array}{l}\text { Developing and } \\
\text { maintaining } \\
\text { associations or } \\
\text { relations with } \\
\text { others. }\end{array}$ & $\begin{array}{ll}- & \text { family } \\
- & \text { social opportunity } \\
- & \text { community }\end{array}$ & $\begin{array}{l}\text { Branscombe/Wann } 1991 \\
\text { Gantz } 1981 \\
\text { Guttman/Smith } 1988 \\
\text { Wenner/Gantz } 1986 \\
\text { Funk } 2001 \\
\text { Jamber } 1999 \\
\text { Weiss/Duncan } 1992\end{array}$ \\
\hline $\begin{array}{l}\text { Emotional } \\
\text { stimulation }\end{array}$ & $\begin{array}{l}\text { Seeking higher } \\
\text { emotional retreat }\end{array}$ & $\begin{array}{ll}- & \text { escape } \\
- & \text { drama } \\
- & \text { risk taking } \\
- & \text { aesthetics } \\
- & \text { eustress } \\
- & \text { stress/stimulation } \\
- & \text { salubrious effects } \\
- & \text { aggression/catharsis } \\
- & \text { entertainment }\end{array}$ & $\begin{array}{l}\text { Madrigal/Howard } 1995 \\
\text { Sloan et al 1987, Wann } \\
\text { 1995, Zuckerman } 1984 \\
\text { Duncan 1983, Smith 1988, } \\
\text { Sloan 1989, Hemphill } \\
\text { 1995' Branscombe/ } \\
\text { Wann 1994, Wann/Gantz } \\
\text { 1989, Gurin/Harris 1985, } \\
\text { Haskell 1987, LeUnes na- } \\
\text { tion 1989. }\end{array}$ \\
\hline Economic & $\begin{array}{l}\text { Potential for } \\
\text { economic gains } \\
\text { through gambling }\end{array}$ & economic & $\begin{array}{l}\text { Gutteman 1986, Chorba- } \\
\text { jian 1978, Crist } 1998\end{array}$ \\
\hline Self-identity & $\begin{array}{l}\text { Create / maintain } \\
\text { positive self } \\
\text { concept }\end{array}$ & $\begin{array}{l}\text { achievement } \\
\text { self-actualization } \\
\text { self-esteem }\end{array}$ & $\begin{array}{l}\text { McClelland et al 1953, } \\
\text { Murray 1938,Kahle et al } \\
\text { 1996, Mahony et al 2002, } \\
\text { Maslow 1970, Gantz 1981, } \\
\text { Csikszentmihayli } 1979\end{array}$ \\
\hline $\begin{array}{l}\text { Information } \\
\text { acquisition }\end{array}$ & $\begin{array}{l}\text { To improve } \\
\text { performance }\end{array}$ & $\begin{array}{l}\text { knowledge } \\
\text { physical fitness }\end{array}$ & $\begin{array}{l}\text { Ryckman/Hamel } \\
\text { 1993,Elay/Page 1999,Koi- } \\
\text { vulos 1999, Brodkin/ } \\
\text { Weiss } 1990\end{array}$ \\
\hline $\begin{array}{l}\text { Group Dis- } \\
\text { association }\end{array}$ & & competition & $\begin{array}{l}\text { Roberts 1984,Williams } \\
1998\end{array}$ \\
\hline
\end{tabular}

Source: own studies 


\section{Proposed Conceptualised model}

Based on the literature a model is proposed which looks at the relations amongst the constructs, depicted in Figure 1. The model looks at the motivations and their affects on situational and enduring involvement. Outcome of this results in brand commitment, personal commitment, level of advocacy and level of usage.

\section{Figure 1}

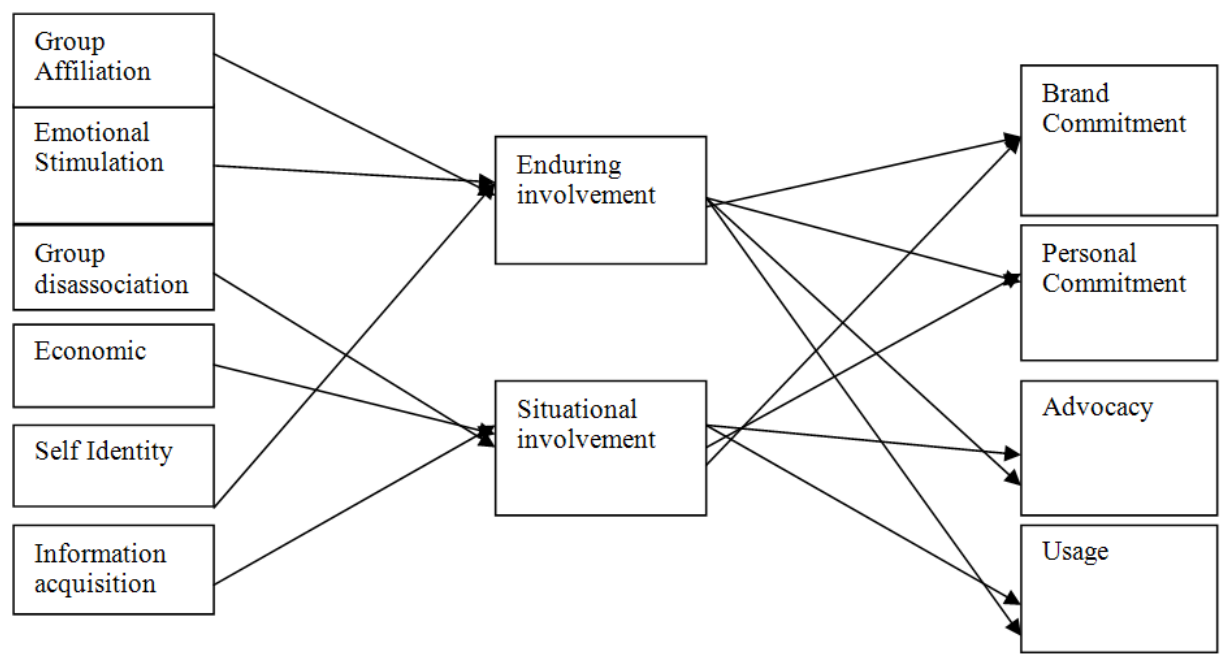

Because of the exploratory nature of this research, the development of direct hypotheses was often not plausible. That is, given the lack of applicable theory and/ or research, it was not appropriate to develop an expectation for each motivational pattern for each sport.

\section{Methodology}

According to Aaker, Kumar and Day (2001), rich data containing consumers' feelings, thoughts, intentions and behaviours can be obtained only through qualitative data collection methods. The methodology of this pilot study consists of a simple survey questionnaire with fans in four different sports in the United Kingdom, the respondents were approached on the same day they attended the sport event and were asked to express their views on their motives to attend this particular sport event.

The sample size for the pilot study was 460 respondents from four different venues in the United Kingdom based on non-probability sampling. The breakdown of the sample can be found table 2 . The sample mainly consisted of males aged between 18 and 70, although some of these were with families and partners. 


\begin{tabular}{|l|l|}
\hline Venue & Sample size \\
\hline Coventry football club & 200 \\
\hline Coventry Rugby club & 100 \\
\hline Warwickshire Coventry cricket club & 100 \\
\hline Coventry bees & 60 \\
\hline
\end{tabular}

Questions asked:

- What motivates you to spend time and money to attend this sporting event? How often do you attend who do you come with?

- What does supporting your team/club gives you?

- Are you committed to your club/team? How and why or why not?

- Are you affected by the performance of the team? How and why?

- When did you first become a fan? Are your family or friends also fans of the team?

- In your opinion are there different types of fans and what type of fan do you consider yourself to be?

- How does being a fan affect your daily life in terms of emotionally, socially and financially?

\section{Findings/discussion}

\section{Group affiliation}

Fans expressed this motive as one of the main reasons to attend Football, Rugby and Cricket matches. "I come to the game because my dad, granddad, brother come to the game". Many of the younger fans became fans of the team from the age of five although many had kits of the team bought for the as soon as they could walk by their parents. "I come to the support the team because my friends came to sport the team". Many fans likened their clubs as extended families to whom they owed a degree of devotion as described in religious terms (Belk et al 1989; Hill 2002). This was especially true of devoted and fanatical fans. They showed great deal of loyalty and commitment to the club by buying merchandise, attending home games and travelling to away games, preseason matches, testimonials, and even training sessions. These groups actively engage in singing and chanting before and during the match and strongly believe that such activities mark them out to as real fans of the team and the backbone of supporters.

Fanatics appear to value and promote the creation of feelings of communitas across likeminded people. Communitas involves feelings of linkage, of belonging, of group devotion to a transcendent goal. In many regards, the fan driven development of communities can be viewed in terms of brand community. Members have an almost encyclopaedic knowledge of the history of the club and celebrate the 
history through prematch or halftime discussions, in which prior events are recollected. Interaction with the club is highly valued. These supporters enthusiastically engage in web site discussions and email commentaries, are keen to in joining supporter groups, and actively seek out and subscribe to newsletter and fanzines. Many of the fans likened their clubs to their extended families to whom they agreed a degree of devotion.

\section{Emotional stimulation}

The strongest motive for fans to attend matches in the different sports was examined in this study. "I enjoy the drama of close games/race", and "I enjoy it when the game is not decided until the very end", "it provides me with excitement stimulation", "game provides a distraction from everyday activities and diversions from life's little problems", "I come to games because I feel bored, lonely, and stressful", were some of the comments made by fans. Majority of the sample selected expressed that attending the sports event is a great opportunity for social interaction and great experience for them. "I enjoy interacting with other spectators at the game", "I enjoy talking with others at the game", "I enjoy going to the game with my friends to socialise", "and I enjoy taking my family to the game. It is a day out for us", "I enjoy socialising with people sitting near me at the game" and "I enjoy watching the athletic performance of the players". I enjoy bringing my clients to games to enhance working relationships", "I enjoy talking with other fans at games", some comments made by fans. Majority of these fans attended games regularly and bought game programmes and pies and drinks, there was high level of brand, personal commitment and high level of loyalty and usage.

\section{Self identity}

Laverie (1992) demonstrated that identity salience is an effective predictor of motivation for participation in a specific leisure activity. This was true in this research as those with high degree of identity with a particular club/venue attended more games. Sport participation tends to absorb fans emotionally, occasionally to an excessive level (Grove et al, 2012). "I go to the game because I am big fan of the team, individual players and venue", "I am loyal to the team by wearing team colours and attend most games", "being a fan is important to me and would experience a loss if I had to stop being a fan", "I identify (Support) the team even when they lose, and, when someone criticizes my team it feels like a personal insult", expressed some of the fans. Fanatical and some of the more devoted fans strongly identified with sports clubs/venues than temporary fans. Temporary fans lacked this strong identification with the club and hence had low commitment to the club and its players. There connection with the club centred on the social event of supporting without any particular emotional attachment to the club or team. Such fans 
elect not to develop close links with their clubs and clearly view their links as largely transactional.

An interesting observation that some of the fans were motivated because of an aggression factor they attended to "come to fight opposing team fans" and "come to swear at opposing team players and referee to get rid of my frustration and to help my team to succeed by putting off players". This type of fans has to be addressed carefully by their respective clubs in order to change and alter their motive in attending the sport events.

\section{Information acquisition}

This was a motive given by number of fans for attending various sport events in this study. "I come to the game because it I increase my understanding of sport (football, cricket, rugby) strategy by watching the game", "I increase my knowledge and technical aspects about football game (same was said in cricket and rugby)", was how they expressed themselves. Most of these fans attended the games once a month and managed non league and junior teams and felt that by watching professional teams it would help to improve their team performances. The most devoted and fanatical fans knew team stats and player information of their team players and information on opposing teams. Community pride played a part in sport fans psychology, fans, viewed the club as the "as the main source of local expression" of the community and attended the sport event because "having a team in the higher league in the city increases community image and represents important symbol for the community".

\section{Economic}

Many fans with high levels of economic motivation were not socialized into the values, beliefs, attitudes and norms associated with sport fandom. They did not perceive themselves as sports fans and did not have particularly high levels of team identification. This motive was the strongest motive to attend dog races. It is the potential gain from sport gambling that attracts them to the role of a fan. Fans were more likely to attend dog racing out of desire to wager on the event. This is reasonable given the reputation of dog racing as gambling sport. There was no evidence from fans in other sports in this study as being the main reason to attend for economic gains. Therefore, many economically motivated fans are by definition, not fans at all. Instead, they participate in the pastime simply for the potential monetary rewards that accrue through sport wagering.

\section{Group dissociation}

Very small minority of fans who attended the sporting event came by themselves, sat by themselves and did not speak to any other fans. They bought a game 
programme and sat in the same seats (area) every time but did not buy any other form of merchandise. In cricket they took packed lunch. This motive was evident in cricket, dog racing and less in football and rugby.

Overall the three strongest motivations were motivations emotional stimulation, group affiliation and group identity.

\section{Implication for sports marketers}

An enhanced understanding of spectator and fan motivation can be of considerable benefit to the sports marketer (James and Ross 2004; Trail et al 2003; Trail and James 2001). The result gleaned from this study (once empirical work has been done) could be of benefit to the marketing professional that is attempting to develop new strategies to reach sports consumers. The development of promotional campaigns and marketing strategies around these sport-specific motives can aid in the marketing of a particular sport, thus driving attendance and consumption. These sport specific motives can be employed by the sport marketer as a method of segmentation and increase additional revenue as consumers are being presented with an increasing number of entertainment options. In-depth understanding of various motivations within sport fans group enables marketers to address them in a way most suitable and meet their needs more fully. Different levels of fanship indicate different needs groups. For practitioners such behaviours give multiple ways to communicate with fans and fulfil their needs for association.

\section{Limitations}

The results of the research are not showcasing any significant culture impact on fandom in sports. In the diverse British society with constant flow of immigrants from variety of countries it's a surprising outcome, indicating that sports unite variety of cultures (Owen 2013). Further research is suggested to provide in-depth exploration of differences in fanship among various cultural groups.

\section{Conclusion}

Motivating fans of sport is an important element for achieving competitive edge within the sport industry; however, in order to achieve this uniqueness, fans classification is crucial for sport organisations. This is because each type of fans requires special attention and hence special targeting and motivation method, some can be motivated by their families and their social backgrounds and others by the sport event itself. Finding the right balance is indeed challenging, nevertheless it is important to start investigating the extents of these motivations within the different sport venues, which will be the second stage of this research. 


\section{Bibliography}

Amine, A. (1988) 'Consumers' true brand loyalty: The central role of commitment', Journal of Strategic Marketing, vol. 6, pp. 305-319

Aaker, D. (1994) 'Building a brand: The Saturn Story', California Management Review, vol. 36, no. 14

Anderson, E.W. (1998) 'Customer satisfaction and word of mouth', Journal of Service Research, vol. 1 , pp. $5-17$

Apostolopoulou, A. (2002) 'Brand extensions by U.S. professional sport teams. Motivations and keys to Success', Sport Marketing Quarterly, vol. 11, pp. 205-214

Ashby, J.S., and Rice, K.G. (2002) 'Perfectionism, Dysfunctional Attitudes, Self-Esteem: A structural Equations Analysis', Journal of Counselling and Development, vol. 80, no 2

Aveni, A.F. (1977) 'The-not-so-lonely crowd. Friendship groups in collective behaviour', Sociometry, vol. 40, pp. 96-99

Ball, A.D. and Taski, L.H. (1992). 'The role and measurement af attachment in consumer behaviour', Journal of Consumer Psychology, vol. 1 no. 2, pp. 155-72

Backman, S.J., and Crompton, J.L. (1991) 'Using loyalty matrix to differientiate between high, spurious, latent and loyal participants in two lesuire services', Journal of Park and Recreation Administration, vol. 9, pp. 1-17

Bandyopadhyay, S. and Bottone, M. (1997) 'Playing to win', Marketing Management. Spring, pp. 9-19

Beatty, S.E., and Kahle, L.R. (1988) 'Alternative hierarchy off the attitude behaviour relationship: the impact of brand commitment and habit', Journal of the Academy of Marketing Science, vol. 16, pp. 1-10

Bech, P. (1994) 'Measurement by observations of aggressive behaviour and activities in clinical situations', Criminal Behaviour and Mental Health, vol. 4, pp. 290-302

Beisser, A. R. (1967) The madness in sports: Psychosocial observations on sports, New York: Warner Brooks.

Belk, R.W. (2004) 'Men and Their Machines', Advances in Consumer Research, vol. 31, pp. 273 278

Branscombe, N.R., and Wann, D.L. (1991) 'He positive social and self concept consequences of sports team identification', Journal of Sports and Social Issues, vol. 15, pp. 115-127

Bristow, D.N., Sebastian R.J. (2001) 'Holy Cow! Wait 'til next year! A Closer Look the Brand Loyalty of Chicago Cubs Baseball Fans'. Journal of Consumer Marketing, vol. 18, no. 3, pp. 256-275

Brooks, C.M. (1994) Sport Marketing: Competitive business strategies for sports. Englewood Cliffs, NJ: Prentice Hall.

Bryant, J. (1989) Viewers' enjoyment of televised sports violence. In. L.A. Wenner (ED), Media, Sports, and Society (pp. 270-289). Newbury Park, CA: Sage.

Bryant, J., Brown, D., Comisky, P.W., and Zillman, D. (1982) 'Sports and spectators: Commentary and appreciation', Journal of Communication, vol. 32, pp. 109-119 
Chadwick, S., and Clowes, J. (1998) 'The use of extension strategies by clubs in the English Football Premier League’, Managing Leisure, vol. 3, pp. 194-203

Christopher, M., Payne, A., and Ballantyne, D. (1991) Relationship Marketing, Sydney: Butterworth-Heinemann

Cialdini, R.B., Borden, R. J., Thirne, A., Walker, M.R., Freeman, S., and Sloan, L. R. (1976) 'Basking in reflected glory: three (football) field studies', Journal of Personality and Social Psychology, vol. 34, pp. 366-375

Cova, B., Cova, V. (2002) 'Tribal Marketing: the tribalisation of society and its impact on the conduct of marketing', European Journal of Marketing, vol. 36, no. 5/6, pp. 595-620

DeSchriver, T.D., and Jenson, P.D. (2002) 'Determinants of spectator attendance at NCAA divison 11 football contests’, Journal of Sport Management, vol. 16, pp. 311-330

Dietz-Uhler, B., Harrick, E.A., End, C., and Jaquemotte, L. (2000) 'Sex difference in sport fan behaviour and reasons for being a sport fan', Journal of Sport Behaviour, vol. 23, pp. 219-232

Doss, E. L., (1999) Elvis Culture: Fans, Faith \& Image, University Press of Kansas: Kansas.

Eastman , S.T., and Land, A.M. (1997) 'The best of both worlds: Sports fans find good seats at the bar', Journal of Sports \& Social Issues, vol. 21, pp. 156-178

Elias, N., and Dunnung, E. (1970) The quest for excitement in unexciting societies. In G. Luschen (ED.), The cross-cultural analysis of sport and games. Champaign, IL; Stipes.

Evaggelinou, C., and Grekinis, D. (1988) 'A survey of spectators at the International Stoke Mandeville Wheelchair Games’, Adapted Physical Education Quarterly, vol. 15, pp. 25-35

Ferrand, A., and Pages, M. (1996) 'Football supporter involvement: Explaining football match loyalty', European Journal for Sports Management, vol. 3, no. 10, pp. 7-20

Fink, J.S., Trail, G.T., \& Anderson, D.F. (2003) 'Environmental factors associated with spectator attendance and sport consumption behaviour: Gender and team differences'. Sport Marketing Quarterly, vol. 11, pp. 8-19

Fisher, R.J., \& Wakefield, K. (1998) 'Factors leading to group identification: A field study of winners and losers', Psychology \& Marketing, vol. 15, no. 1, pp. 23-40

Fiske, S.T. and Taylor, S.E. (1984) Social Cognition, Addison-Wesley Publishing: Reading, MA.

Fournier, S. (1998) 'Consumers and their brands: Developing Relationship Theory in Consumer Research', Journal of Consumer Research, vol. 22, pp. 343-373

Fournier, S., Yao, J.L. (1997) 'Reviving brand loyalty: A reconceptualization within the framework of consumer - brand relationships', International Journal of Research in Marketing, vol. 14, pp. 451-472

Fournier, S. (1998) 'Consumers and their brands: Developing Relationship Theory in Consumer Research', Journal of Consumer Research, vol. 22, pp. 343-373

Funk, D.C. (1998) Fan Loyalty: The Structure and Stability of an Individual's Loyalty toward an Athletic Team. Unpublished Doctoral Dissertation. Columbous: Ohio State University 
Funk, D.C., and James, J.D (2001) 'The Psychological Continuum Model: A conceptual framework for understanding an individual's psychological connection to sport', Sport Management Review, vol. 4, pp. 119-150

Funk, D.C., Mahony, D.F., \& Ridinger, L.L. (2002) 'Characterizing consumer motivation as individual difference factors: Augmenting the sport interest inventory (SII) to explain levels of spectator sport', Sport Marketing Quarterly, vol. 11, pp. 33-43

Funk, D.C., \& Pastore, D.L. (2000). 'Equating attitudes to allegiance: The usefulness of selected attitudinal information in segmenting loyalty to professional sports teams', Sport Marketing Quarterly, vol. 9, pp. 175-184

Gantz, W. (1981) 'An exploration of viewing motives and behaviours associated with television sports', Journal of Broadcasting, vol. 25, pp. 263-275

Gantz, W., and Wenner, L.A. (1995) 'Fanship and television sports viewing experience', Sociology of Sports Journal, vol. 12, pp. 56-74

Gmelch, G., and San Antonio, P.M. (1998) 'Groupies and American baseball', Journal of Sport \& Social Issues, vol. 22, pp. 32-45

Gibson, H.,Willming, C., Holdnak, A. (2002) 'We're Gators... Not Just Gator Fans: Serious Leisure', University of Florida Football.

Gladden, J.M., and Funk, D.C. (2001) 'Developing an understanding of brand associations in the team sport: empirical evidence from consumers of professional sport', Journal of Sport Management, vol. 16, no. 1, pp. 54-81

Gladden, J.M. \& Milne, G.R. (1998) 'Examining the importance of brand equity in professional sports', Sports Marketing Quarterly, vol. 8, no. 1, pp. 21-29

Grove, J.R., Hanrahan, S.J., \& McInman, A. (1991) 'Success/failure bias in attributions across involvement categories in sport', Personality and Social Psychology Bulletin, vol. 17, pp. 93-97

Grove, S., Pickett, G., Jones, S., Dorsch, M. (2012) 'Spectator Rage as the dark side of Engaging Sport Fans: Implications for Service Marketers', Journal for Service Research, vol. 2012, pp. 1-18

Guttmann, A. (1986) Sports spectators, New York: Columbia University Press

Hansen, H., and Gauthier, R. (1989). 'A means - ends chain model based on consumer categorization processes', Journal of Marketing, vol. 46, no. 2, pp. 60-72

Homburg, C., \& Giering, A. (1999) The measurement of brand satisfaction and brand loyalty. Modern Brand Management: Fundamentals, new approaches, implementation, Germany: Gabler.

Hirt, E.R., Zillmann, D., Erickson, G.A., and Kennedy, C. (1992) 'Costs and benefits of allegiance: Changes in fans' self-ascribed competencies after team victory versus defeat', Journal of Personality and Social Psychology, vol. 63, pp. 724-738

Huffman, C., Ratneshwar, S., Mick, D.G. (2000) Consumer goal structures and gold-determination processes: An integrative framework, in Ratneshwar, S., Mick, D. G., Huffman, C., (2000) The Why of Consumption: Contemporary Perspectives on Consumer Motives, Goals, and Desires, Routledge: London \& New York. 
Hugenberg, B., (2002) 'Communicatively Constructed Stakeholder Idenity: A Critical Ethnography of Cleveland Browns Fan Culture'. Unpublished Doctoral Dissertation. Bowling Green: Bowling Green State University.

Hunt, K. A., Bristol, T., Bashaw, E.R. (1999) 'A Conceptual Approach to Classifying Sports Fans', Journal of Services Marketing, vol. 13, no. 6, pp. 439-452

Jacoby, J., and Kyner, D.B. (1973) 'Brand loyalty vs. Repeat purchasing behaviour', Journal of Marketing Research, vol. 10, pp. 1-9

Jamber, E.A. (1999) 'Parent as children's socializing agents in youth soccer', Journal of Sports Behaviour, vol. 22, no. 3, pp. 350-359

James, J.D., (1997) Becoming a sports fan: understanding cognitive development and socialization in the development of fan loyalty. Unpublished Doctoral Dissertaion. Columbus: The Ohio State University

Jones, I. (1997) 'A further examination of the factors influencing current identification with a sports team', a response to Wann et al (1996) 'Perceptual and Motor Skills', vol. 85, pp. $257-8$

Kahle, L.R., Kambara, K.M., Rose, G. (1996) 'A function model of fan attendance motivations for college football', Sport Marketing Quarterly, vol. 5, no. 4, pp. 51-60.

Keaton, S. and Gearhart, C. (2014) 'Identity formation, identity strength and self-categorisation as predictors of affective and psychological outcomes', vol. 2, no. 4, pp. 363-385

Koivula, N. (1999) 'Sport participation: Differences in motivation and actual participation due to gender typing', Journal of Sports Behaviour, vol. 22, no. 3, pp. 360-380

Kozinets, R.V. (2001) 'Utopian Enterprise: Articulating the Meaning Star Trek's Culture of Consumption', Journal of Consumer Research, vol. 24, pp. 479-475

Keaveney, S.M., \& Hunt, K.A. (1992) 'Conceptualization and operationalization of retail store image: a case of rival middle - level theories', Journal of the Academy of Marketing Science, vol. 15, pp. 165-76

LeUnes, A.D., \& Nation, J.R. (1989) Sport Psychology; An introduction. Chicago: Nelson-Hall Inc.

Madrigal, R. (1995) 'Cognitive and affective determinants of fan satisfaction with sporting event attendance', Journal of Leisure Research, vol. 27, pp. 205-227

Madrigal, R. \& Howard, D.R. (1999) Measuring the multidimensional nature of spectators' attraction to sports events, International Journal of Sport Management, vol. 1, pp. 154-180

Mahony, D.F., Madrigal, R., \& Howard, D. (2000) 'Using the psychological commitment to a team (PCT) scale to segment sport consumer based loyalty', Sport Marketing Quarterly, vol. 9, pp. 15-25

Mann, L. (1974) 'On being a sore loser: How fans react to their team's failure', Australian Journal of Psychology, vol. 26, pp. 37-47

Mann, L. (1969) 'Queue culture: the waiting line as a social system', American Journal of Sociology, vol. 75 , pp. $340-354$

Mano, H., \& Oliver, R.L. (1993) 'Assessing the dimensionality and structure of the con- 
sumption experience: Evaluation, feeling, and satisfaction', Journal of Consumer Research, vol. 20, pp. 451-466

Maslow, A.H. (1943) 'A Theory of Human Motivation', Psychological Review, vol. 50, pp. 370396

Mechikoff. R.A. (1992) 'Deep Fan: Mythic Identification, Technology and Advertising in Spectator Sports', Sociology of Sport Journal, vol. 9, no. 4. pp. 323-339

Melnick, M. and Wann, D. (2011) 'An examination of sport fandom in Australia: Socialisation, team identification and fan behaviour', International Review for the Sociology of Sport, vol. 46, no. 4, pp. 456-470

Meyer, J.P., \& Allen, N.J. (1984) 'Testing the side bet theory of organizational commitment: Some methodological considerations', Journal of Applied Psychology, vol. 69, pp. 372-378

Muniz, A., O’Guinn, T.C., (2001) 'Brand Community', Journal of Consumer Research, vol. 27, pp. $412-432$

McAlexander, J.H., Schouten, J.W., Koenig, H.F., (2002) 'Building Brand Community', Journal of Marketing, vol. 66, pp. 38-54

Nash, R. (2002) 'Contestation in Modern English Professional Football: The independent Supporters Association Movement', International Review for the Sociology of Sport, vol.35, no. 4, pp. $465-486$

Ngobo, P.V. (2004) 'Drivers of customers cross - buying intentions', European Journal of Marketing, vol. 38, pp. 1129-1157

Oliver, R.L. (1999) 'Whence Consumer Loyalty?', Journal of Marketing, vol. 63, pp. 33-44

O’Reilly, C. \& Chatman, J. (1996) 'Organizational commitment and psychological attachment: the effects of compliance, identification, and internalization on prosocial behaviour', Journal of Applied Psychology, vol. 71, pp. 492-99

Owen, D. (2013) Future Identities: Changing identities in the UK - the next 10 years, Government Office for Science

Paffenbarger, R.S., \& Lee, I. (1996) 'Physical activity and fitness for health and longevity', Research Quarterly for Exercise and Sport, vol. 67, no. 30, pp. 11-28

Pan, D.W., Gabert, T.E., McGaugh, E.C., \& Branvold, S.E. (1997) 'Factors and differential demographic effects on purchases of season tickets for intercollegiate basketball games', Journal of Sport Behaviour, vol. 20, pp. 447-464

Pimentel, R. W., Reynolds, K.W., (2004) 'A model for consumer devotion: affective commitment with proactive sustaining behaviour', Academy of Marketing Science Review vol. 2004, no. 5, pp. $1-45$

Pritchard, M.P., Havitz, M.E., \& Howard, D.R. (1999) 'Analyzing the commitment-loyalty link in service contexts', Journal of the Academy of Marketing Science, vol. 27, pp. 333-348

Quick, S. (2000) 'Contemporary sport consumers: some implications of linking fan typology with key spectator variables', Sport Marketing Quarterly, vol. 9, no. 3, pp. 149-156

Quirk, K. (1997) Not now, honey, I'm watching the game. New York: Fireside. 
Rozanski, H.D., Baum A.G., Wolfsen, B.T., (1999) 'Brand Zealots: Realizing the Full Value of Emotional Brand Loyalty', Strategy+business, vol. 17, pp. 51-62

Redden, J., \& Steiner, C.J. (2000) 'Fanatical consumers: towards a framework for research', Journal of Consumer Marketing, vol. 17, no. 4, pp. 322-337

Richin, M.C., \& Bloch, P.H. (1986) 'After the new wears off: The temporal context of product involvement', Journal of Consumer Research, vol. 13, pp. 280-285

Rifkin, G., (1999) 'How the Red Sox Touch All the Branding Bases', Strategy and business, vol. 17, pp. 75-83

Rinehart, R. (1996) 'Dropping hierarchies: Toward the study of a contemporary sporting avant-garde' Sociology of Sport Journal, vol. 13, pp. 159-175

Ruiz, F. (2001) 'The relationship between coginitive dissonance and helping behaviour', Japanese Psychological Research, vol. 43. no. 3

Sergeant, S.L., Zillmann, D., \& Weaver, J. B.III. (1998) 'The gender gap in the enjoyment of televised sports', Journal of Sport \& Social Issues, vol. 22, pp. 46-64

Sapolsky, B.S. (1980) 'The effect of spectator disposition and suspense on the enjoyment of sport contests', International Journal of Sport Psychology, vol. 11, pp. 1-10

Shank, M.D., \& Beasley, F.M. (1998) 'Fan or Fanatic: refining measure of sports involvement', Journal of Sports Behaviour, vol. 21, pp. 435-443

Sjoestreoem, N., Eder, D.N., Malm, U., \& Beskow, J. (2001) 'Violence and its prediction at a psychiatric hospital', European Psychiatry, vol. 16, pp. 459-465

Sloan, L.R. (1989) 'The Motive of Sports fans'. In J.D Goldstein (ED), Sports, games and play: Social and psychosocial viewpoints, Hillsdale, NJ: Lawarence Erlbaum Associates.

Smith, G.J. (1988) 'The Noble Sports Fan', Journal of Sports \& Social Issues, vol. 12, pp. 54-65

Snyder, C. R., Higgins, R.L., \& Stuckhy R. J. (1983) Excuses: Masquerades in search of grace, New York: Wiley Interscience.

Stebbons, R. (2010) New directions in theory and research of serious leisure. Lewiston, NY: Edwin Mellen Press.

Sutton, W.A., McDonald, M.A., Milne,G.R., \& Cimperman, J. (1997) 'Creating and fostering fan identification in professional sports', Sports Marketing Quarterly, vol. 6, no. 1997, pp. $15-22$

Su-Lin, G., Tuggle, C.A., Mitrook, M.A., Coussement, S. H., \& Zillman, D. (1997) 'The thrill of a close game: Who enjoys it and who doesn't??', Journal of Sport \& Social Issues, vol. 21, pp. 53-64

Tapp, A., \& Clowes, J. (2000) 'From “Carefree Casuals" to "Professional Wanderers" Segmentation Possibilities for Football Supporters', European Journal of Marketing, vol. 36, no. 11-12, pp. 45-59

Tomasson, K. \& Vaglum, P. (1996) 'Psychopathology and alcohol consumption among treatments seeking alcoholics: a prospective study', Addictions, vol. 91, pp. 1019-1030

Trail, G. T., Robinson, M.J., \& Gillentine, A.J., (2003) 'Motives and points of attachment: 
Fans versus spectators in intercollegiate athletics', Sport Marketing Quarterly, vol. 12, pp. $217-227$

Wakefield, K.L., and Wann. D.L. (2006) 'An Examination of Dysfunctional Sports Fans: Method of Classification and Relationships with Problem Behaviours', Journal of Leisure Research, vol. 38, no. 2, pp. 168-186

Wann, D.L. (2006) 'The causes and consequences of sport team identification'. In: A.A. Raney and J. Brayant, Editors, Handbook of Sports and Media, Erlbaum, Mahwah, NJ

Wann, D.L. and Branscombe, N.R. (1993) 'Sports Fans: Measuring the Degree of Identification with their team', International Journal of Sports Psychology, vol. 26, pp. 551-7

Wann, D.L., Schrader, M. P., \& Wilson, A. M. (1999) 'Sport fan motivation: Questionnaire validation, comparison by sport, and relationship to athletic motivation', Journal of Sport Behaviour, vol. 22, pp. 114-139

Wann, D.L., Tucker, K., and Schrader, M. (1996) 'An exploratory examination of the factors influencing the origination, continuation and cessation of identification with sports teams', Perceptual and Motor Skills, vol. 82, pp. 995-1001

Whang, Y.O., Allen, J., Sahoury, N., Zhang, H., (2004) 'Falling in love with a product: The Structure of a Romantic Consumer- Product Relationship', Advances in Consumer Research, vol. 31, pp. 320-327

Wann, D. L., \& Dolan, T.J. (1994) 'Attributions of highly identified sport spectators', The Journal of Social Psychology, vol. 134, pp. 279-286

Wann, D.L., Melinick, M.J., Russell, G.W., \& Pease, D.G. (2001) Sport fans: The psychology and social impact of spectators. New York: Routledge.

Weiller, K.H., \& Higgs, C.T. (1997) 'Fandom in the 40's: the integrating functions of All American Girls Professional Baseball League', Journal of Sport Behaviour, vol. 20, pp. 211231

Weiss, M.R., \& Duncan, S.C.(1992) 'The relationship between physical competence and peer acceptance in the context of children's sports participation', Journal of Sports \& Exercise Psychology, vol. 14, pp. 177-191

Zillman, D., Bryant, J., \& Sapolsky, B.S. (1989) 'Enjoyment from sports spectatorship'. In J.H. Goldstein, Sports, games, and play: Social and psychological viewpoints. Hillsdale, NJ: Erlbaum.

Zuckerman, M. (1984) 'Sensation-seeking: A comparative approach to a human behaviour', The Behavioural and Brain Sciences, vol. 7, pp. 413-471

Appendix 3 Sample size breakdown

\begin{tabular}{|l|l|}
\hline Venue & Sample size \\
\hline Coventry football club & 200 \\
\hline Coventry Rugby club & 100 \\
\hline Warwickshire Coventry cricket club & 100 \\
\hline Coventry bees & 60 \\
\hline
\end{tabular}

